\title{
MUHAMMAD ARSYAD THALIB LUBIS (1908-1972): ULAMA YANG MEMBESARKAN AL JAM'IYATUL WASHLIYAH
}

\author{
M. Rozali \\ Universitas Dharmawangsa Medan \\ Jl. KL Yos Sudarso No.224, Glugur Kota, Medan, Sumatera Utara \\ aboezaid@gmail.com
}

\begin{abstract}
Abstrak
Tulisan ini bertujuan untuk menjelaskan tentang Muhammad Arsyad Thalib Lubis yang merupakan ulama yang membesarkan Al Jam'iyatul Washliyah. Muhammad Arsyad Thalib Lubis memberikan kontribusi yang besar dalam memajukan Al Jam'iyatul Washliyah yaitu menjaga stabilitas masyarakat dan meningkatkan pendidikan di Sumatera Utara adalah merupakan keinginan umat dan berbarengan dengan cita-cita bangsa dalam mencerdaskan rakyat. Tulisannya menjelaskan menjelaskan aktivitas seorang tokoh besar Al Washliyah dalam Pendidikan, dakwah, sosial dan politik.
\end{abstract}

\section{Abstract}

The purpose of this paper is to explain about Muhammad Arsyad Thalib Lubis who is a scholar who raised Al Jam'iyatul Washliyah. Muhammad Arsyad Thalib Lubis made a big contribution in advancing Al Jam'iyatul Washliyah, namely maintaining the stability of society and improving education in North Sumatra is the desire of the people and coincides with the ideals of the nation in educating the people. His writing explains the activities of a major figure in Al Washliyah in Education, da'wah, social and politics.

Kata Kunci: Muhammad Arsyad Thalib, Ulama, Al Jam'iyatul Washliyah 


\section{Rozali}

\section{Pendahuluan}

Muhammad Arsyad Thalib Lubis tidak dapat dipisahkan dari sejarah tradisi keulamaan Al Jam'iyatul Washliyah Sumatera Utara. Dikenal sebagai ulama, pejuang, muballigh dan pejuang agama Islam di Sumatera Utara. Bahkan ulama multi talenta ini sudah mendapatkan pengakuan dari dunia luar dalam bidang keilmuan dan dakwah beliau dalam menghadapi missionaris dan berdakwah di tengah-tengah masyarakat Batak pedalaman.

Kontribusi Muhammad Arsyad Thalib Lubis, bersama Al Jam'iyatul Washliyah dalam menjaga stabilitas masyarakat dan meningkatkan pendidikan di Sumatera Utara adalah merupakan keinginan umat dan berbarengan dengan cita-cita bangsa dalam mencerdaskan rakyat. Dalam menyebarkan agama Islam di Sumatera Utara, peran Muhammad Arsyad Thalib Lubis (1908-1972), tidak bisa diragukan. Murid Hasan Maksum (1884-1936) ini dikenal sebagai 'Kristologi Besar dari Sumatera'.' Selain kegiatan berdakwah menyiarkan dan menyebarkan agama Islam dengan cara berdialog dan berdiskusi dengan sesama pemuka agama lain, beliau juga dikenal sebagai dosen di Universitas AI Washliyah (1958-1972), dan Universitas Islam Sumatera Utara (1954-1957).

Tulisan sederhana ini berusaha menjelaskan aktivitas seorang tokoh besar Al Washliyah dalam Pendidikan, dakwah, sosial dan politik. Aktivitas yang dilakukan oleh Muhammad Arsyad Thalib Lubis ini mengangkat reputasi Al Washliyah sehingga dikenal di seluruh pelosok Indonesia.

\section{Biografi}

Muhammad Arsyad Thalib Lubis, lahir pada "Bulan Oktober 1908 atau bertepatan Ramadhan 1326 H. di kota Stabat, kabupaten Langkat Sumatera Utara dari pasangan yang sangat berbahagia pemuka agama Islam Lebai Thalib bin Ibrahim Lubis dengan Markoyom Nasution (Kuyon)".2 "Ayahnya berasal dari kampong Pastap, Kotanopan Kabupaten Tapanuli Selatan, kemudian menetap di Stabat sebagai petani yang agamis sehingga beliau mendapat panggilan 'Lebai' merupakan panggilan kehormatan di daerahnya atas ilmu agama yang dimiliki" ${ }^{3}$

Muhammad Arsyad Thalib Lubis, menjalani seluruh pendidikannya di Sumatera Utara, pendidikan dasar ditamatkan di Sekolah Rakyat Stabat, Madrasah Islam (Ibtidaiyah) Stabat (1917-1920), Madrasah Islam (Tsanawiyah) Binjai (1921-

1http://insistnet.com. Diakses pada tanggal 19 Februari 2015.

2Pengurus Besar Al Jam'iyatul Washliyah, Debat Islam dan Kristen Tentang Kitab Suci, cet. 2 (Medan: Majelis Dakwah Pengurus Besar Al Jam'iyatul Washliyah, 2002), h. 27.

${ }^{3}$ www.kabarwashliyah.com. Diakses tanggal 12 Agustus 2015. 
1922), kemudian pada tahun 1923 dilanjutkan ke Kota Tanjungbalai Asahan, di Madrasah Ulumul Arabiyah yang dipimpin Abdul Hamid (1923-1924). ${ }^{4}$ Kemudian beliau pindah ke Medan di Madrasah al-Hasaniyah (1925-1930) berguru dengan Hasan Maksum, ulama yang cukup terkenal dan harum sampai saat ini. ${ }^{5}$

Murid Hasan Maksum, ini selain dikenal sebagai pendiri dan pernah menjadi Ketua Umum Pengurus Besar Al Jam'iyatul Washliyah, "beliau juga pernah belajar ilmu-ilmu agama kepada Muhammad Yasin bin Muhammad Isa al-Padani (19151990) di Makkah. ${ }^{6}$ Dari kedua ulama ini, silsilah keilmuannya menyambung sampai pada ulama-ulama Syafi'iyah terkemuka di Timur Tengah". ${ }^{7}$

Muhammad Arsyad Thalib Lubis, merupakan seorang murid yang kreatif dan produktif dalam tulis menulis, "pada usia dua puluh enam tahun sudah menulis buku yang pertama dengan judul: Rahasia Bibel (1926)". ${ }^{8}$ Buku ini menjadi pegangan atau rujukan para dai dalam penyebaran Islam. Tidak hanya berhenti di situ banyak lagi karangan beliau yang lain, karya tersebut dibagi kepada tiga kategori: Pertama: Jawaban terhadap berbagai isu kontemporer. Kedua: Pendidikan dan Syariat Islam. Ketiga: Hal-hal yang berhubungan dengan dakwah dan gerakan, sehingga banyak ilmuwan Indonesia dan Malaysia mengakui keunggulan karyakarya beliau, salah satu yang paling monumental adalah buku: Perbandingan Agama Islam dan Kristen diterbitkan pertama kali di Medan pada tahun 1969.

Buku setebal 494 ini dibagi menjadi dua jilid, "diterbitkan kembali oleh penerbit Firma Islamyah Medan pada tahun 1983. Buku ini terakhir kali dicetak pada tahun 1982 di Malaysia. Sehingga seorang ahli perbandingan agama dari

${ }^{4}$ Sejarah keilmuannya dapat dilacak jauh hingga ke Kerajaan Asahan, Sumatera Utara. Dua tahun setelah berakhirnya Perang Dunia I, tepatnya tahun 1916 M, Abdul Hamid dan temantemannya mendirikan satu instansi pendidikan Islam yang diberi nama Madrasah al-'Ulum al'Arabiyah. Madrasah ini menjadi instansi pendidikan ternama di Asahan, bahkan di Sumatera Utara, disamping ada Madrasah Islam Stabat-Langkat, Madrasah Islam Binjai, dan Madrasah al-Hasaniyah di Medan. Lihat: www.kabarwashliyah.com. Diakses tanggal 12 Agustus 2015.

${ }^{5}$ Muhammad Arsyad Thalib Lubis, Debat Islam-Kristen Tentang Kitab Suci (Jakarta: Pengurus Besar Al Washliyah, 2002), hlm. 27.

${ }^{6}$ Muhammad Yasin bin Muhammad Isa al-Padani, adalah rektor Dar al-'Ulum Makkah (madrasah kedua setelah madrasah Shaulatiyah, tempat orang-orang Indonesia belajar). Lihat: Martin Van Bruinessen, Kitab Kuning, Pesantren dan Tarekat (Yogyakarta: Gading Publishing, 2012), hlm. 108-109.

7Ja'far, Biografi Intelektual Ulama-Ulama Al Washliyah (Medan: Centre for Al Washliyah Studies, 2012), hlm. 55.

${ }^{8}$ http://insistnet.com, diakses tanggal 19 Februari 2015. 


\section{Rozali}

Universitas Islam Internasional Malaysia, Kamaroniah Kamaruzzaman, memuji kualitas karya Muhammad Arsyad Thalib Lubis tersebut". ${ }^{9}$ Kandungan buku ini membandingkan beberapa ajaran penting yang ada dalam Islam dan Kristen, seperti: "pokok ajaran Islam-Kristen, dosa warisan, penebusan dosa, ketuhanan Yesus, kitab-kitab suci: Taurat, Zabur, Injil dan Alquran, dan Nubuwat Nabi Muhammad dalam Bibel. Intinya, Muhammad Arsyad Thalib Lubis banyak mengkaji secara kritis dogma-dogma Kristen lewat kacamata tulisan sarjana Kristen, Islam, dan melalui rasio". ${ }^{10}$

Muhammad Arsyad Thalib Lubis, memperdalam berbagai keilmuan mulai dari "Tafsir, Hadis, Tauhid, Fikih, Usul Fikih, Sejarah dan Kristologi. Keahlian di bidang Kristologi ini membuat nama beliau melambung tinggi, sehingga dikenal sebagai Kristologi Besar dari Sumatera".11 Dalam bidang Kristologi beliau tidak diragukan lagi, dengan menguasai sejarah dan doktrin agama-agama, khususnya Yahudi dan Nasrani secara mendalam, sehingga menjadikannya lebih nyaman dan efektif berdakwah menyebarkan syiar Islam di Sumatera Utara. Selain kegiatan berdakwah menyiarkan dan menyebarkan agama Islam dengan cara berdialog dan berdiskusi dengan sesama pemuka agama lain, beliau juga dikenal sebagai pengajar di Universitas Al Washliyah (1958-1972 M), dan Universitas Islam Sumatera Utara (1954-1957 M).

Berkat ketekunannya dalam menuntu ilmu, maka pada usia delapan belas tahun Muhammad Arsyad Thalib Lubis muda mendapatkan kepercayaan untuk menjadi guru di Madrasah Al Jam'iyatul Washliyah (1926-1930). Selanjutnya beliau juga mengajar pada beberapa madrasah lain baik di Sumatera Utara maupun di Aceh. Di antara madrasah tersebut adalah; Madrasah al-Irsyadiyah Medan, Madrasah Al Washliyah Meulaboh Aceh, Madrasah Al Jam'iyatul Washliyah Medan, Madrasah al-Qismul Ali Tebing Tinggi, dan Madrasah al-Qismul Ali Al Jam'iyatul Washliyah jalan Ismailiyah Medan. Berikutnya beliau juga menjadi dosen di beberapa perguruan tinggi di Kota Medan, antara lain; Sekolah Persiapan Perguruan Tinggi Islam Indonesia Medan. Beliau juga dikukuhkan sebagai guru besar ilmu fikih dan ushul fikih di Universitas Islam Sumatera Utara dan dosen tetap di Universitas Al Washliyah dari awal berdiri sampai akhir hayatnya.

Di Madrasah Al Jam'iyatul Washliyah Jalan Ismailiyah Medan, Muhammad Arsyad Thalib Lubis, mengajar sejumlah kitab seperti tasawuf menggunakan kitab Risālah Qusyairiyah, dalam bidang fikih beliau mengajarkan kitab al-Mạ alli karya

\footnotetext{
${ }^{9} \mathrm{http} / / /$ insistnet.com, diakses tanggal 19 Februari 2015.

${ }^{10} \mathrm{http}: / /$ insistnet.com, diakses tanggal 19 Februari 2015.

${ }^{11} \mathrm{http}: / /$ insistnet.com, diakses tanggal 19 Februari 2015.
} 
Jalāl ad-Dīn al-Maḥ alli, Syarh Jalā / ad-Dīn al-Mạ̣ alli ala Jam'u al-Jawā mi’karya alSubki dan al-Asybāh wa an- Nazāōir karya Jalāl ad-Dīn as-Suyūți. Dalam bidang retorika beliau mengajarkan kitab Adab al-Munaẓarah karya Muhammad alMar'asyi. Dalam bidang perbandingan agama yang diajarkan al-Adyan karangan Mahmud Yunus. Dalam bidang tafsir beliau mengajarkan Anwār at-Tanzīl wa Asrār at-Ta'wil (Tafsīr al-Baị awi) karya Qāọi Nasiruddīn al-Baiḍawi, Lubāb at-Ta'wil fí Ma'āni at-Tanzil (Tafsìr al-Khazinn) karya 'Ala' ad-Dīn 'Ali bin Mụ̣ammad bin Ibrāhīm al-Bagdā dī al-Khazīn, Madā ruk at-Tanzīl wa Haqā 'iq at-Ta'wil (Tafsìr anNasafi) karya Abdullah bin Ạ̣mad bin Mạ̣mud an-Nasafī dan Tanwīr al-Mikbā S min Tafsīr Ibnu 'Abbās karya Muḥammad bin Ya'kūb bin Faḍillah al-Fairūzābā dī Majīd ad-Dīn Abū aț-T ahir. ${ }^{12}$

Melihat banyaknya bidang studi yang ajarkan oleh Muhammad Arsyad Thalib Lubis, menunjukkan bahwa beliau memiliki kemampuan dalam memahami dan mengajarkan kembali beberapa kitab tersebut. Beberapa kitab tersebut merupakan karya monumental dari beberapa ulama Sunni yang sudah terkenal di Timur Tengah. Sementara Muhammad Arsyad Thalib Lubis tidak pernah belajar di Timur Tengah sebelumnya. Pelajaran-pelajaran mengenai beberapa disiplin ilmu tersebut diperoleh dari gurunya Hasan Maksum, dan kemudian mengajarkan kepada murid-muridnya.

Beliau mendapat kepercayaan dari gurunya yakni Mahmud Ismail Lubis (1900-1937), untuk menyalin karangan yang akan dimuat di surat kabar. Pada usia 20 tahun, beliau telah menjadi penulis di majalah Fajar Islam di Medan. ${ }^{13}$ Pada usia 26 tahun beliau menghasilkan sebuah buku perdananya yang diberi judul Rahasia Bible terbit pada tahun 1934 dan dicetak ulang pada tahun 1936. Buku ini kemudian menjadi pegangan para muballigh dan dai Al Jam'iyatul Washliyah dalam menyebarkan agama Islam di Porsea Kabupaten Tapanuli Utara.

Muhammad Arsyad Thalib Lubis yang tiada henti-hentinya mendorong sahabat-sahabatnya terutama Abdurrahman Syihab (1910-1955) untuk mengembangkan Debating Club ini menjadi organisasi Islam. Akhirnya Abdurrahman Syihab, Muhammad Arsyad Thalib Lubis bersama sahabatsahabatnya yang lain seperti Ismail Banda, Udin Syamsuddin, Adenan Lubis, pada tanggal 30 Nopember 1930 resmi mendirikan organisasi pergerakan perjuangan yang diberi nama Al Jam'iyatul Washliyah yang mengutamakan pilar-pilar

12 Ja'far, Biografi Intelektual Ulama-Ulama A/ Washliyah (Medan: Centre for Al Washliyah Studies, 2012), h. 61.

${ }^{13}$ www.kabarwashliyah.com, diakses tanggal 12 Agustus 2015. 


\section{Rozali}

perjuangan sebagai wadah pergerakan pendidikan, pergerakan dakwah dan pergerakan amal sosial. ${ }^{14}$

Muhammad Arsyad Thalib Lubis, pemuda yang gigih tanpa mengenal menyerah ini di samping aktif mengajar dan berdakwah, beliau sangat aktif menulis, mengarang bahkan pada tahun 1937, menerbitkan sebuah majalah yang diberi nama 'Dewan Islam'.

Majalah ini popular pada masa itu disebabkan isinya memperjuangkan agama Islam pada era penjajahan Belanda. Majalah ini juga banyak memuat tulisan tokoh-tokoh terkenal baik dari dalam dan luar negeri seperti Osman Raliby dan Adenan Lubis, namun akhirnya majalah Dewan Islam menghentikan penerbitannya karena pendudukan Jepang dan meletusnya perang dunia ke II tahun 1942. ${ }^{15}$

Dalam kegiatan dakwah beliau aktif dalam zending (muballigh) Islam Indonesia, melakukan dakwah ke kampong-kampung dengan berjalan kaki untuk menyiarkan Islam di pedalaman Tanah Karo. Perjuangan yang dilakukannya tanpa henti ini menuai hasil yang memuaskan dengan masuk Islamnya puluhan ribu orang dari daerah tempatnya berdakwah. Bahkan menjelang akhir hayatnya beliau juga masih menyempatkan diri untuk pergi ke Kutalimbaru, Kabupaten Deli Serdang, untuk mengislaman sekitar dua ratus orang masyarakat di sana. Di samping berdakwah, beliau juga membagi-bagikan secara gratis buku-buku karangannya tentang shalat, iman dan ibadah dalam bahasa Karo, Nias dan Simalungun.

Penjajahan Jepang di Indonesia menjadikan kehidupan masyarakat semakin sulit. Berbagai kegiatan yang dilakukan organisasi senantiasa dipantau dan diawasi, sehingga tidak ada kebebasan untuk berekspresi. Para aktivis yang selama ini memperjuangkan kemerdekaan diajak untuk bergabung dengan tentara Jepang. Bagi yang tidak mau mengikuti keinginan Jepang akan bernasib buruk, maka pada masa itu, Muhammad Arsyad Thalib Lubis lebih memilih menjadi petani daripada bekerjasama dengan penjajah Jepang. Walaupun demikian dengan keberanian yang luar biasa sebagai seorang pejuang 1945, beliau berusaha membangkitkan semangat perjuangan rakyat Indonesia di Sumatera Utara dengan menulis buku yang berjudul Tuntunan Perang Sabil, buku ini ditulis dengan tujuan untuk membangkitkan semangat pemuda-pemuda Islam melawan tentara Belanda dan Jepang. Walaupun dengan semangat juang pantang menyerah dan tidak ada

14 Muhammad Arsyad Thalib Lubis, Debat Islam-Kristen Tentang Kitab Suci (Jakarta: Pengurus Besar Al Washliyah, 2002), h. 28.

15 Muhammad Arsyad Thalib Lubis, Debat Islam-Kristen Tentang Kitab Suci (Jakarta: Pengurus Besar Al Washliyah, 2002), h. 28-29. 
waktu untuk berkompromi terhadap penjajah, memaksa Muhammad Arsyad Thalib Lubis harus dimasukkan oleh Belanda ke dalam tahanan Sukamulia Medan pada tahun 1948, dan saat itu pula kedukaan yang tidak pernah terlupakan terjadi pada beliau, istri tercinta dipanggil Allah pada usia 35 tahun. ${ }^{16}$

Perjuangan yang dilakukan oleh Muhammad Arsyad Thalib Lubis dalam memperjuangkan kemerdekaan tidak hanya dengan bertempur di medan perang, akan tetapi beliau terus menuangkan berbagai strategi melalui ide-ide kreatif yang dipublikasikan lewat tulisan. Walau pada akhirnya beliau sendiri harus dikurung dalam tahanan oleh penjajah. Berbagai siksaan dan tekanan yang dihadapi dalam masa tahanan tidak menjadikannya surut untuk berjuang, terutama menegakkan kalimat tauhid di Sumatera Utara.

Setelah mengalami masa-masa yang sulit mulai dari penjajahan Belanda dan Jepang pada tahun 1941-1945, Muhammad Arsyad Thalib Lubis, selalu menyibukkan diri dengan mengembangkan pendidikan madrasah-madrasah Al Jam'iyatul Washliyah. Setelah Kemerdekaan Indonesia pada tahun 1945 beliau turut serta dalam mengisi kemerdekaan melalui organisasi Al Jam'iyatul Washliyah dan beberapa jabatan penting di pemerintahan, di antaranya adalah sebagai Kepala Mahkamah Syari'ah dan Kepala Jawatan Urusan Agama Keresidenan Sumatera Timur, serta Kepala Kantor Urusan Agama Sumatera Utara. Selain itu beliau juga menuangkan ilmunya di beberapa perguruan tinggi di Sumatera yaitu Universitas Islam Sumatera Utara (UISU) dan Universitas AI Washliyah (UNIVA) Medan dan pada akhirnya beliau diangkat sebagai guru besar Ushul Fikih dan Fikih di Universias Islam Sumatera Utara (UISU) sampai tahun 1957.17

Muhammad Arsyad Thalib Lubis, sosok ulama yang sangat dihormati dan disegani tidak hanya oleh masyarakat tanpa memandang status, aliran, agama apa saja, akan tetapi oleh pemerintah dan pemimpin-pemimpin Islam. Lebih dari itu beliau juga dikenal sebagai orang yang rendah hati, hal itu sebagaimana yang terungkap pada saat M. Natsir memberikan perhatian kegembiraan terhadap kecemerlangan Muhammad Arsyad Thalib Lubis, dengan mencantumkan gelar Professor di depan namanya saat Dewan Dakwah Islamiyah Indonesia menerbitkan buku karangan Muhammad Arsyad Thalib Lubis yang berjudul Keesaan Tuhan Menurut Ajaran Kristen dan Islam. "Secara halus beliau menolaknya, walaupun pada

16 Muhammad Arsyad Thalib Lubis, Debat Islam-Kristen Tentang Kitab Suci (Jakarta: Pengurus Besar Al Washliyah, 2002), h. 29-30.

17 Ja'far, Biografi Intelektual Ulama-Ulama A/ Washliyah (Medan: Centre for Al Washliyah Studies, 2012), h. 63. 


\section{Rozali}

dasarnya semua orang memandang pantas beliau menyandang gelar ini". ${ }^{18}$

Dalam bidang politik, Muhammad Arsyad Thalib Lubis, memiliki hubungan yang sangat dekat dengan M. Natsir semasa aktif berjuang bersama di Partai Masyumi. Kedekatan ini karena Al Jam'iyatul Washliyah dan Muhammadiyah adalah merupakan anggota istimewa Masyumi. Pada masa pergolakan kemerdekaan Indonesia Al Jam'iyatul Washliyah tetap aktif melaksanakan tugasnya sebagai anggota istimewa. Di mana saja diadakan penerangan untuk mencari dana biaya perjuangan senantiasa mendapat sambutan dari rakyat dan memberikan sumbangan ikhlas. Pernah dalam suatu rapat akbar dipanggung bioskop Binjai yang dibanjiri kaum Muslimin/Muslimat dan anggota Al Washliyah dalam rapat akbar mana dalam rangka mencari dana dan biaya perjuangan untuk pembeli senjata dan pelor dan lain sebagainya. Hadir ketika itu Pengurus Besar Al Washliyah sebagai pengurus Masyumi Sumatera Utara, di antaranya adalah: Abdurrahman Syihab, Muhammad Arsyad Thalib Lubis dan Udin Syamsuddin, untuk memberi penerangan. Maka mengalirlah sumbangan dari kaum Muslimin/Muslimat yang hadir dalam rapat akbar itu, bukan saja berupa uang tapi bagi yang tidak membawa uang baik kaum ibu dan bapak ada yang membuka cincin dari jarinya, ada yang memberikan jam tangannya dan kaum ibu ada yang memberikan kerabu dan rantenya. Bahkan ada yang tidak punya apa-apa, langsung memberikan sepedanya yang digunakan untuk menggalas tapi dengan ikhlas rasa turut bertanggungjawab memberikan sepedanya itu untuk biaya perjuangan kemerdekaan Indonesia. Ketika Abdurrahman Syihab berbicara di atas podium, ketika itu juga beliau membuka baju jas yang dipakainya diberikan untuk perjuangan dan diikuti oleh hadirin. ${ }^{19}$

Muhammad Arsyad Thalib Lubis adalah ulama yang komplit, beliau sebagai guru, pengarang, orator, pejuang, politikus dan jujur. Bahkan beliau tidak ingin terkontaminasi dengan berbagai suara yang melingkarinya, oleh karena itu pula Muhammad Arsyad Thalib Lubis seakan menjauh dari kehidupan para pejabat dan kehidupan hartawan, walaupun perhatian pejabat dan hartawan sangat perduli terhadapnya. Beliau ulama berani, tidak pengecut dalam semua aspek kehidupan, karena itulah motto hidupnya jelas, tegas dan diamalkannya secara konsisten tanpa

18 Muhammad Arsyad Thalib Lubis, Debat Islam-Kristen Tentang Kitab Suci (Jakarta: Pengurus Besar Al Washliyah, 2002), h. 32.

19 Hakimuddin Lubis, Bulan Sabit Berbintang Lima Dalam Kenangan Hidup H. Djalaluddin Lubis (Medan: t.p., 1980), h. 36-37. 
rasa ragu "biar kurus asal lurus". ${ }^{20}$

Bahrum Jamil, selaku murid dan pendiri Universitas Islam Sumatera Utara (UISU) juga pernah menjadi Ketua Umum Pengurus Besar Al Jam'iyatul Washliyah mengungkapkan bahwa "Muhammad Arsyad Thalib Lubis merupakan seorang ulama, mujahid dan assyida'u 'ala al-kuffār ruhamā 'u bainahum". ${ }^{21}$ Begitu juga muridnya Muhammad Ridwan Lubis, mantan Ketua Umum Pengurus Besar (19871997) dan mantan Dewan Fatwa Pengurus Besar Al Jam'iyatul Washliyah, menyatakan bahwa "Muhammad Arsyad Thalib Lubis pernah berpesan di bawah menara Sofa tanah suci Makkah pada tahun 1972, sebagai berikut: selama Al Jam'iyatul Washliyah sebagai alat untuk mengembangkan ajaran Islam, peliharalah ia dengan baik, kembangkanlah dan perjuangkanlah ia, ingat aku mengajar, aku menulis, aku berorganisasi dan aku berjuang". ${ }^{22}$

Apa yang dijelaskan Bahrum Jamil dan Muhammad Ridwan Lubis, tentang gurunya ini adalah suatu penghargaan dan penghormatan yang besar terhadap sosok ulama yang pernah memimpin organisasi terbesar di Sumatera Utara ini. Muhammad Arsyad Thalib Lubis, seakan mengetahui tentang kondisi Al Jam'iyatul Washliyah pada masa yang akan datang. Sehingga beliau berpesan kepada muridnya agar memelihara Al Jam'iyatul Washliyah selama ia masih digunakan untuk mengembangkan ajaran Islam. Muhammad Arsyad Thalib Lubis, juga seakan ingin menyadarkan generasi-generasi berikutnya bagaimana susah dan payahnya beliau dalam membesarkan nama Al Jam'iyatul Washliyah yang telah memperbaiki pengetahuan masyarakat Sumatera Utara terhadap Islam di mata dunia.

Dalam usia dua puluh enam tahun Muhammad Arsyad Thalib Lubis sudah menulis buku yang pertama dengan judul Rahasia Bibel (1926). Buku ini menjadi pegangan atau rujukan para dai dalam penyebaran Islam. Selain menulis buku tersebut beliau juga banyak menghasilkan berbagai buku lainnya, beberapa karya tersebut dapat dilihat pada tabel berikut ini:

\section{Tulisan Muhammad Arsyad Thalib Lubis}

\section{\begin{tabular}{l|l|r} 
No & Kategori Buku Judul
\end{tabular}}

20 Muhammad Arsyad Thalib Lubis, Debat Islam-Kristen Tentang Kitab Suci (Jakarta: Pengurus Besar Al Washliyah, 2002), h. 33.

21 Muhammad Arsyad Thalib Lubis, Debat Islam-Kristen Tentang Kitab Suci (Jakarta: Pengurus Besar Al Washliyah, 2002), h. 33.

22 Muhammad Arsyad Thalib Lubis, Debat Islam-Kristen Tentang Kitab Suci (Jakarta: Pengurus Besar Al Washliyah, 2002), h. 33. 


\section{Rozali}

\begin{tabular}{|c|c|c|}
\hline (1) & (2) & (3) \\
\hline 1 & Fatwa & $\begin{array}{l}\text { Fatwa (Medan: Firma Islamyah, 1982), Islam di } \\
\text { Polen (Medan: Boekhandel Islamijah, 1939), } \\
\text { Tuntunan Perang Sabil, Imam Mahdi, Ruh Islam, } \\
\text { Pembahasan Sekitar Nuzul Quran, dan Kisah Isra' } \\
\text { Mi'raj. }\end{array}$ \\
\hline 2 & $\begin{array}{l}\text { Pendidikan } \\
\text { dan Syariat } \\
\text { Islam }\end{array}$ & $\begin{array}{l}\text { Tola Wamati Ba Ugamo Islam (Medan: Majelis } \\
\text { Ulama Indonesia, 1968), Bena-Bena Kepertjajaen } \\
\text { Ibagessen (Medan: Majelis Ulama Indonesia, } \\
\text { 1968), Bona Ni Haporseaon Dibagasan Agama } \\
\text { Islam (Medan: Majelis Ulama Indonesia, t.t.), } \\
\text { Dasaring Kapertjajan Ing Agama Islam (Medan: } \\
\text { Majelis Ulama Indonesia, t.t.), Peladjaran } \\
\text { Sembahjang (Medan: Majelis Ulama Indonesia, } \\
\text { 1966), Pelajaran Iman (Medan: Sumber IImu Jaya, } \\
\text { 1950), Pelajaran Ibadat (Medan: Sumber IImu Jaya, } \\
\text { 1950), al-Qawāid al-Fiqhiyyah (Medan, Sumber } \\
\text { Ilmu Jaya, 1959), al-'Aqāid al-Imāniyah (Medan: } \\
\text { Sumber IImu Jaya, 1959), IImu Fikih (Medan: Firma } \\
\text { Islamyah, 1982), IImu Pembagian Pusaka (al- } \\
\text { Faraidh) (Medan: Firma Islamya, 1980), } \\
\text { Persiadjaran Sombajang (Medan: Dakwah Liga } \\
\text { Musjawarah Muslimin, 1969). Pedoman Mati } \\
\text { Menurut Alquran dan al-Hadis (Medan: Islamyah, } \\
\text { 1984), Pelajaran Tauhid (Jakarta: Sumber Bahagia, } \\
\text { t.t.), Pemimpin Haji Mabrur (Medan: Firma } \\
\text { Islamya, 1966), Riwayat Nabi Muhammad SAW } \\
\text { (Medan: Sumber IImu Jaya, 1951), Agama Islam, } \\
\text { Pelajaran Istilahatal-Muhaddisin, al-Ushul min IImi } \\
\text { al-Ushul, Ihtisar Riwayat Nabi-nabi; dan Himpunan } \\
\text { Doa Nabi-nabi dan Orang Shaleh dalam Alquran. }\end{array}$ \\
\hline 3 & $\begin{array}{l}\text { Hal-hal yang } \\
\text { berhubungan } \\
\text { dengan } \\
\text { dakwah dan } \\
\text { gerakan }\end{array}$ & $\begin{array}{l}\text { Perbandingan Agama Kristen dan Islam (Medan: } \\
\text { Firma Islamyah, 1971), Debat Islam - Kristen } \\
\text { tentang Kitab Suci (Jakarta: Pengurus Besar Al } \\
\text { Washliyah, 2002), Keesaan Tuhan Menurut Ajaran } \\
\text { Islam dan Kristen (Jakarta: Hudaya, 2006), Rahasia } \\
\text { Bibel, Jaminan Kemerdekaan Beragama Islam; dan }\end{array}$ \\
\hline
\end{tabular}




\section{Berdialog dengan Kristen Adven}

Beberapa karya Muhammad Arsyad Thalib Lubis ini masih bisa ditemukan di Perpustakaan Majelis Ulama Indonesia (MUI) Sumatera Utara. Kurangnya perhatian dari Pengurus Besar Al Jam'iyatul Washliyah untuk mengkoleksi dan menyediakan perpustakaan yang layak terhadap karya-karya ulama-ulama Al Jam'iyatul Washliyah, sehingga Yayasan Baitul Makmur yang dulu dipercayakan menjaga buku-buku tersebut harus menitipkan ke Perpustakaan Majelis Ulama Indonesia (MUI) Sumatera Utara, sebagian buku-buku ditemukan sudah dalam keadaan rusak dan lapuk. Berdasarkan penelusuran yang penulis lakukan di perpustakaan Majelis Ulama Indonesia (MUI) Sumatera Utara ditemukan beberapa buku yang ditulis menggunakan bahasa daerah, baik bahasa Mandailing, Batak dan karo.

Dari karya-karya yang pernah dihasilkan oleh Muhammad Arsyad Thalib Lubis ini, maka tidak sedikit para ilmuwan baik dari Indonesia maupun negeri tetangga yang mengakui keunggulan karya-karya tersebut, salah satu karya yang paling monumental adalah buku: Perbandingan Agama Kristen dan Islam diterbitkan pertama kali di Medan pada tahun 1969. Buku setebal 478 ini diterbitkan kembali oleh penerbit Firma Islamiyah Medan pada tahun 1983. Di Malaysia, buku ini terakhir kali dicetak tahun 1982 dan sempat dilarang beredar pada masa pemerintahan Orde Baru. ${ }^{23}$ Pakar perbandingan agama dari Universitas Islam Internasional Malaysia, Kamaroniah Kamaruzzaman, memuji kualitas karya Muhammad Arsyad Thalib Lubis tersebut. Dalam buku ini dibandingkan beberapa ajaran penting yang ada dalam Islam dan Kristen, seperti: pokok ajaran IslamKristen, dosa warisan, penebusan dosa, ketuhanan Yesus, kitab-kitab suci: Taurat, Zabur, Injil dan Alquran, dan nubuwat Nabi Muhammad dalam Bibel. Intinya, Muhammad Arsyad Thalib Lubis banyak mengkaji secara kritis dogma-dogma Kristen lewat kacamata tulisan sarjana Kristen, Islam, dan rasio. ${ }^{24}$

Murid dari Hasan Maksum ini memperdalam berbagai keilmuan mulai dari tafsir, hadis, tauhid, Fikih, usul Fikih, sejarah dan kristologi. Keahlian di bidang kristologi ini membuat nama beliau melambung tinggi, sehingga dikenal sebagai "Kristologi Besar dari Sumatera". Dalam bidang kristologi beliau tidak diragukan lagi, dengan menguasai sejarah dan doktrin agama-agama, khususnya Yahudi dan Nasrani secara mendalam, sehingga menjadikannya lebih nyaman dan efektif berdakwah menyebarkan syiar Islam di Sumatera Utara. Selain kegiatan berdakwah

23 Fauzi Usman, Ketua Yayasan Madrasah Al Jam'iyatul Washliyah Jalan Ismailiyah Medan, wawancara di Medan tanggal 25 Juli 2015.

24 http://insistnet.com. Diakses tanggal 19 Februari 2015. 


\section{Rozali}

menyiarkan dan menyebarkan agama Islam dengan cara berdialog dan berdiskusi dengan sesama pemuka agama lain beliau juga dikenal sebagai pengajar di Universitas Al Washliyah (1958-1972), dan Universitas Islam Sumatera Utara (19541957).

\section{Aktivitas Dakwah}

Dalam bidang dakwah aktivitas pengislaman di Sumatera Timur dipimpin oleh guru kitab yang begitu mahir dengan Injil (Beybel) yaitu: "Abdul Qadir dan pimpinan Al Jam'iyatul Washliyah Muhammad Arsyad Thalib Lubis, adalah pejuang yang gigih menghadapi kristenisasi dan menegakkan hukum Islam dalam segala lapangan". ${ }^{25}$ Salah satu tugas dakwah Al Jam'iyatul Washliyah adalah menyampaikan dakwah Islamiah kepada orang yang belum beragama Islam terutamanya kepada masyarakat Batak.

Perlu dikaitkan dengan kenyataan yang terdapat dalam Enseklopedi Islam tentang seorang pendakwah terkenal, ulama terkemuka, penulis yang produktif, pendidik dan juga seorang tokoh penting Al Jam'iyatul Washliyah, yaitu Muhammad Arsyad Thalib Lubis, sebagai berikut: Keluasan dan kedalaman ilmunya yang ditunjang dengan kemampuan dalam menyusun hujah-hujah yang kuat berdasarkan Alquran dan Sunnah serta pemikiran yang logis serta kemampuan retorika yang memikat, telah memungkinnya untuk sukses dalam dunia dakwah, baik terhadap masyarakat Islam sendiri maupun masyarakat pedalaman yang menganut paham animisme di Sumatera Utara. Ceramahnya mengasyikkan bukan hanya bagi kalangan mahasiswa dan pelajar namun seluruh lapisan masyarakat. Muhammad Arsyad Thalib Lubis berdakwah bukan hanya di daerah perkotaan saja, tetapi mencapai daerah-daerah terpencil di daerah pedalaman. Dengan dakwah yang dilakukannya bersama beberapa dai lainnya telah berhasil mengislamkan ribuan penduduk animisme di pedalaman Sumatera utara. ${ }^{26}$

Nizar Syarif, mengatakan bahwa pada masa penumpasan gerakan Partai Komunis di Indonesia, Muhammad Arsyad Thalib Lubis pernah memberikan ceramah di lapangan Merdeka Medan, Sumatera utara yang dihadiri oleh lautan manusia, ribuan orang yang terdiri dari para pemuda dan lain-lain. ${ }^{27}$ Sejarah lain dalam perkembangan dakwah Al Jam'iyatul Washliyah juga terjadi dengan

${ }^{25}$ A. Djalil Muhammad dan Abdullah Syah, Sejarah Da'wah Islamiyah dan Perkembangannya di Sumatera Utara (Medan: Majelis Ulama Daerah TK. I Provinsi Sumatera Utara, t.t.), h. 53.

26 Tim Penulis Institut Agama Islam Negeri (IAIN) Syarif Hidayatullah, Ensiklopedia Islam Indonesia (Jakarta: Djambatan, 1992), h. 670.

27 Nizar Syarif, mantan Ketua Pimpinan Wilayah Al Jam'iyatul Washliyah Sumatera Utara, wawancara di Medan, tanggal 23 Juli 2015. 
perdebatan atau dialog keagamaan antara pemuka agama yang berbeda, hal ini terjadi pada tahun 1935, terjadi perdebatan antara dai Al Jam'iyatul Washliyah dengan seorang pendeta Kristen. Ketika rombongan pendakwah yang dipimpin oleh Guru Kitab Sibarani menuju perkampungan untuk menyampaikan dakwah. Setelah menyelesaikan salat secara berjamaah, mereka kehadiran sekumpulan pendeta dan pengikutnya yang berjumlah sekitar lima puluh orang, di antara mereka ada pendeta yang berkewarganegaraan Eropa dengan membawa Alquran dan mengeluarkan penghinaan terhadap para dai Al Jam'iyatul Washliyah, dengan ungkapan sebagai berikut: 'Kamu adalah orang-orang yang baru masuk Islam dan tidak paham makna ucapan-ucapan dan bacaan-bacaan yang kamu lakukan'. Katakata penghinaan pendeta ini mengakibatkan terjadinya perdebatan. Untuk menjawab penghinaan tersebut, Guru Kitab Sibarani selaku ketua rombongan sepontan mengatakan: 'Tuan adalah seorang yang terpelajar, sudah pasti tuan lebih mengerti firman-firman tuhan yang terdapat dalam Bibel dan Alquran, dijelaskan bahwa seseorang tidak boleh menghina orang lain di depan orang ramai, siapa yang menghina orang lain maka dia akan dihina oleh tuhan kelak. Menurut saya, bukan saya yang tidak paham tetapi tuanlah yang belum paham terhadap apa yang dikatakan di dalam Alquran. Perdebatan tersebut memakan waktu yang panjang, karena masing-masing mempertahankan keyakinannya dengan berbagai argumen. Karena banyaknya pertanyaan-pertanyaan yang diajukan oleh Guru Kitab Sibarani yang tidak bisa dijawab, akhirnya para pendeta dan rombongannya meninggalkan dai Al Jam'iyatul Washliyah. ${ }^{28}$

Selain berdakwah ke pelosok-pelosok, maka untuk mengoptimalkan aktivitas dakwah dipandang perlu untuk menyebarkan Islam melalui media cetak atau surat kabar maupun majalah. Berdasarkan pertimbangan tersebut maka Muhammad Arsyad Thalib Lubis, ditunjuk untuk pimimpin redaksi majalah Medan Islam, beliau memang memiliki pengetahuan yang luas tentang agama Kristen. Dalam memimpin majalah Medan Islam beliau bukan saja bisa menulis sebuah artikel yang mengulas informasi-informasi tentang agama Kristen akan tetapi mampu menguraikan penyimpangan-penyimbangan dan pemalsuan-pemalsuan terhadap Injil, kitab suci agama Kristen atau yang lebih dikenal dengan Perjanjian Baru. ${ }^{29}$

${ }^{28}$ Syamsuddin Ali Nasution, Al Jam'iyatul Washliyah dan Perannya dalam Dakwah Islamiyah di Indonesia (Disertasi: Universitas Malaya Kuala Lumpur, 2001), h. 273.

${ }^{29}$ Syamsuddin Ali Nasution, Al Jam'iyatul Washliyah dan Perannya dalam Dakwah Islamiyah di Indonesia (Disertasi: Universitas Malaya Kuala Lumpur, 2001), h. 264. 


\section{Rozali}

Dalam perjalanannya majalah Medan Islam, akhirnya terpaksa dilakukan pergantian pemimpin, walaupun demikian Muhammad Arsyad Thalib Lubis tidak lupa melaksanakan tugasnya dalam membela Islam. Mengenai hal ini, dijelaskan sebagai berikut: "Medan Islam menyediakan ruangan percaturan agama, pada umumnya mengenai agama Kristen. Sebagian besar isi ruangan ini adalah pembelaan terhadap kebenaran Islam dan memaparkan kelemahan Kristen". ${ }^{30}$ Selain permasalahan tersebut, Medan Islam juga menguraikan masalah-masalah yang berkaitan dengan: fikih, hadis, sejarah Rasul dan selalu disesuaikan dengan perkembangan up to date seperti bulan suci Ramadhan, hari raya idul fitri dan lain sebagainya.

Satu hal yang tak kalah pentingnya dalam artikel-artikel ini adalah disediakannya ruang-ruang untuk bahasa Indonesia, Inggris dan Arab. Hal ini sangat jelas menggambarkan bahwa majalah ini juga bertujuan untuk meningkatkan kemampuan para pembaca dalam bahasa-bahasa tersebut. ${ }^{31}$ Bahasa-bahasa tersebut memang merupakan alat komunikasi masa dalam tingkat nasional maupun internasional. Sebagai salah satu sarana komunikasi dan informasi terkini pada masanya, Medan Islam juga mengambil bagian dalam membahas isuisu kontemporer, yang mana perannya sangat penting terutama sekali pada masamasa genting. Hal ini terbukti mana kala Indonesia menyatakan kemerdekaannya pada tanggal 17 Agustus 1945, majalah Medan Islam menerbitkan artikel atau makalah tentang perlunya membela kemerdekaan. ${ }^{32}$

Melihat keberadaan surat kabar dan majalah lain sangat sedikit pada masa menjelang kemerdekaan Indonesia, majalah Medan Islam sudah tentu mendapatkan sambutan hangat dari berbagai pihak, baik anggota Al Jam'iyatul Washliyah maupun masyarakat luas. Keadaan tersebut terbukti dengan besarnya angka penjualan majalah tersebut yang mencapai belasan ribu eksemplar, yaitu sebanyak 14.980 eksemplar. ${ }^{33}$

Selain majalah Medan Islam masih ada lagi majalah lain yang dikelola oleh ulama Al Jam'iyatul Washliyah yaitu: Raudhatul Muta'allimin. Dari nama tersebut

\footnotetext{
${ }^{30}$ Chalidjah Hasanuddin, Al Jam'iyatul Washliyah 1930-1942: Api Dalam Sekam di Sumatera Timur (Bandung: Pustaka, 1988), h. 102.

${ }^{31}$ Chalidjah Hasanuddin, Al Jam'iyatul Washliyah 1930-1942: Api Dalam Sekam di Sumatera Timur (Bandung: Pustaka, 1988), h. 103.

${ }^{32}$ Nukman Sulaiman, Peringatan: Al Djamijatul Washlijah 1/4 Abad (Medan: Pengurus Besar Al Djamijatul Washlijah, 1955), h. 126.

${ }^{33}$ Chalidjah Hasanuddin, Al Jam'iyatul Washliyah 1930-1942: Api Dalam Sekam di Sumatera Timur (Bandung: Pustaka, 1988), h. 103.
} 
sudah tergambar bahwa pembaca dan peminat majalah yang diterbitkan setiap bulan tersebut adalah para pelajar dan mahasiswa. Adapun yang menjadi kandungan majalah Raudhatul Muta'allimin adalah terdiri dari berbagai makalah dan pembahasan-pembahasan. Di antaranya adalah ruangan ilmu pengetahuan, sejarah, kesehatan, pendidikan, keputrian, keteladanan, peristiwa dan berita institusi perguruan atau pendidikan. ${ }^{34}$ Dari ruang artikel ini dapat dipahami bahwa maksud penerbitan majalah ini adalah untuk meningkatkan dan memperluas pengetahuan para pelajar khususnya, serta memberikan informasi-informasi kontemporer.

Melihat realitas yang ada, walau bagaimanapun peran penting yang dimainkan oleh majalah pelajar ini, jika tidak didukung oleh sumber dana yang kuat maka lambat laun akan segera padam juga. Hal inilah yang dialami majalah yang didirikan pada bulan Februari 1937 ini, dikarenakan hal tersebut ia hanya mampu menerbitkan 11 edisi. ${ }^{35}$ Nasib yang sama juga dialami oleh majalah Medan Islam yang harus undur diri dari dunia tulis menulis sebelum tahun 60-an.

Ulama Al Jam'iyatul Washliyah dalam menerbitkan majalah-majalahnya telah ambil bagian dalam usaha untuk meningkatkan wawasan masyarakat dan berusaha menyadarkan umat Islam tentang tugas dan kewajiban mereka. Selain itu sebagai organisasi besar, usaha-usaha penerbitan majalah dipandang penting bagi Al Jam'iyatul Washliyah. Penerbitan ini membantu masyarakat untuk mengetahui informasi-informasi tentang Islam di berbagai belahan dunia lain, sebab dewasa ini media-media cetak maupun elektronik di Indonesia seperti dikebiri dalam menerbitkan berita atau tulisan yang berhubungan dengan Islam. Hal ini sebagaimana disampaikan oleh Jan Ali, yang mengatakan bahwa "Media don't want to talk about the goodness of Islam because the media don't like Islam". 66

Tahun 1938, Muhammad Arsyad Thalib Lubis mengelola sebuah majalah yang berjudul Dewan Islam yang diterbitkan oleh Badan Penerbit Dewan Islam, beralamat di jalan Japaris No. 421 A, Medan. Sedangkan alamat kantor administrasinya terletak di jalan Japaris No. 217, Medan. Muhammad Arsyad Thalib Lubis menjabat sebagai Pemimpin Pengarang dan Moehammad Sa'ad sebagai Pengurus. Majalah Dewan Islam terbit setiap bulan berisi reportase dan artikel yang

${ }^{34}$ Nukman Sulaiman, Peringatan: A/ Djamijatul Washlijah 1/4 Abad (Medan: Pengurus Besar Al Djamijatul Washlijah, 1955), h. 77.

${ }^{35}$ Nukman Sulaiman, Peringatan: Al Djamijatul Washlijah 1/4 Abad (Medan: Pengurus Besar Al Djamijatul Washlijah, 1955), h. 77.

${ }^{36} \mathrm{Jan}$ Ali, Lecturer in Islam and Modernity in the School of Humanities and Communication Arts University of Western Sydney, wawancara di Sydney tanggal 16 September 2015. 


\section{Rozali}

berhubungan dengan Islam. Dalam edisi No. 42/Tahun V/Juni 1938, misalnya ada tulisan tentang kehidupan kaum Muslim di Jepang dan lain-lain.

Tahun 1955, Muhammad Arsyad Thalib Lubis dan beberapa ulama lain, seperti Zainal Arifin Abbas, aktif dalam penulisan di majalah al-Islam yang diterbitkan oleh Firma Islamyah, Medan. Alamat kantor redaksi terletak di jalan Sutomo P No. 329, Medan. Pemimpin Umum majalah al-Islam adalah Abdul Djalil Siregar, Pemimpin Redaksi Zainal Arifin Abbas, Staf Redaksi Nashiruddin D. Pane, Abdul Mu'thi. Redaksi Harian Moehd. Noer Hanafiah, anggota-anggota Muhammad Arsyad Thalib Lubis, M. Bustami Ibrahim, Adnan Lubis, Abdul Halim Hasan dan M. Dien Yatim. Majalah ini terbit setiap bulan, memuat artikel-artikel mengenai agama Islam dan hal-hal umum lain yang dilihat dari kacamata Islam. Majalah al-Islam memuat artikel-artikel tentang keislaman yang ditulis oleh ulamaulama terkemuka pada tahun 1955, seperti Zainal Arifin Abbas, Adnan Lubis, Tamar Djaja, Hamka, Oemar Amin Hoesin, Abdul Qadir 'Oudah, Abd. Halim Hasan, Mohd. Noerman, Hamzah Junus, M. Ali Sardjany, dan lain-lain.

Selain majalah yang diterbitkan oleh Al Jam'iyatul Washliyah, ada juga tulisan-tulisan lain dalam bentuk buletin dan buku, baik yang berukuran kecil, sedang dan besar. Buletin dan buku-buku tersebut juga berusaha untuk memberikan penjelasan atau pencerahan kepada masyarakat luas tentang hukumhukum Islam, fenomena masyarakat dan pendidikan. Para ulama Al Jam'iyatul Washliyah menulis buletin dan buku-buku tersebut dengan dalil yang jelas, tersusun dengan bukti-bukti atau fakta-fakta yang membenarkan atau menolak suatu hal yang bertantangan dengan ajaran Islam. Karena itu berdakwah melalui tulisan juga tidak kalah pentingnya dengan beberapa cara lain untuk menyampaikan ajaran Islam.

Usaha ulama Al Jam'iyatul Washliyah untuk mengembangkan ajaran Islam di Sumatera Utara dilakukan dengan berbagai cara. Selain menerbitkan majalah, buletin juga merupakan usaha yang sangat praktis untuk menyampaikan ajaran Islam di kalangan masyarakat luas. Buletin dipandang lebih efisien karena gampang dibaca di mana saja, karena terdiri dari beberapa halaman dan merupakan santapan rohani untuk golongan intelek dan golongan terpelajar yang hanya membahas tema-tema tertentu saja. ${ }^{37}$ Buletin dakwah yang menggunakan bahasa Indonesia ini mengandung artikel atau makalah pendek tentang Islam, terdiri dari ayat-ayat Alquran, hadis Rasul dan diperkuat dengan pendapat para ulama yang berkaitan dengan hal-hal yang sedang dibahas.

${ }^{37}$ Syamsuddin Ali Nasution, Al Jam'iyatul Washliyah dan Perannya dalam Dakwah Islamiyah di Indonesia (Disertasi: Universitas Malaya Kuala Lumpur, 2001), h. 270. 
Buletin ini hanya mampu diterbitkan sekitar 300-500 eksemplar saja setiap kali terbit dan hanya membahas tiga hingga lima tema saja setiap tahunnya. Cara mendistribusikan buletin ini juga masih sangat sederhana, yaitu melalui kantorkantor kepengurusan Al Jam'iyatul Washliyah di daerah-daerah, selanjutnya disampaikan kepada para pengurus, Majelis Taklim dan lain sebagainya. Setiap buletin yang disampaikan akan dikenakan biaya dengan harga tertentu yang relatif murah. ${ }^{38}$

Setelah melalui beberapa media, melihat kebutuhan dan kepentingan penulisan buku sebagai sarana dakwah, ulama al-Jam'iayatul Washliyah berusaha mencetak dan menerbitkan buku-buku dalam berbagai tema dan judul menurut kepentingan atau keperluan berbagai lapisan masyarakat. Perhatian al-Jam'iayatul Washliyah terhadap penerbitan buku dibuktikan dengan dibentuknya sebuah majelis yang bertugas mengawasi hal ini, yaitu: "Majelis Pembacaan/Penerbitan", pada tahun 1934. ${ }^{39}$ Dalam tulisan ini peneliti berusaha untuk memaparkan sebanyak mungkin buku-buku yang ditulis oleh ulama-ulama Al Jam'iyatul Washliyah dalam menyebarkan agama Islam.

Mengingat perkembangan-perkembangan dakwah yang dilakukan di daerah-daerah minoritas Muslim setelah pengiriman para dai di wilayah-wilayah tersebut. Maka dirasa penting untuk membekali para muallaf dengan buku-buku pegangan yang bisa mereka jadikan sebagai pedoman dalam menjalankan syariat Islam. Maka ulama Al Jam'iyatul Washliyah melakukan usaha-usaha untuk menerbitkan buku-buku agama pada tanggal 7 September 1934, yang merupakan hasil usaha para Pengurus Pusat, adapun buku-buku tersebut di antaranya adalah: (a) Peraturan Sembahyang; (b) Pangaramotan tu na Mate (Mengurus Jenazah); (c) Hite to Hasilomon I (Jalan ke Islam). ${ }^{40}$

Ketiga buku-buku di atas diterbitkan dalam bahasa Toba yang ditulis oleh: Abdul Kadir, seorang ulama yang fasih berbahasa Toba dan gigih dalam mengembangkan dakwah Islam. Biaya penerbitan buku-buku ini diperoleh dari wakaf para dermawan di kota Medan. Buku-buku tersebut sangat jelas bertujuan untuk memberikan pemahaman kepada umat Islam di tanah Batak dan sekitarnya.

${ }^{38}$ Departemen Agama Republik Indonesia, Organisasi A/ Washliyah di Sumatera Utara (Semarang: Balai Penelitian Aliran Kerohanian/Keagamaan, 1994), h. 177.

${ }^{39}$ Nukman Sulaiman, Peringatan: Al Djamijatul Washlijah 1/4 Abad (Medan: Pengurus Besar Al Djamijatul Washlijah, 1955), h. 77.

${ }^{40}$ Nukman Sulaiman, Peringatan: Al Djamijatul Washlijah 1/4 Abad (Medan: Pengurus Besar Al Djamijatul Washlijah, 1955), h. 52. 


\section{Rozali}

Sebanyak 5000 eksemplar berhasil di sebarkan di Porsea, diberikan kepada masyarakat Muslim di sana secara gratis. ${ }^{41}$

Selain-buku-buku tersebut yang ditulis dengan bahasa Toba, ulama Al Jam'iyatul Washliyah juga mengambil inisiatif untuk menerbitkan dua buku yang berjudul: (a) Pedoman Gendek (Pedoman Ringkas); (b) Turi-turian Gendek (Riwayat ringkas tentang kebesaran nabi Muhammad Saw). ${ }^{42}$ Buku-buku ini berasal dari bahasa Melayu karya Zainal Arifin Abbas, selanjutnya diterjemahkan ke dalam bahasa Karo oleh Gr. Terang Ginting. ${ }^{43}$ Buku ini diterbitkan untuk disebarkan di Tanah Karo, guna menambah pemahaman kaum Muslimin tentang syariat Islam terutama berkaitan dengan kewajiban-kewajiban yang harus dilaksanakan dalam kehidupan sehari-hari sebagai seorang Muslim, serta tentang sejarah perjuangan Rasulullah menegakkan agama Islam, sebab pemahaman mereka tentang hal-hal tersebut masih sangat dangkal sekali.

Selain buku-buku yang telah disebutkan di atas masih banyak lagi terbitanterbitan lain yang berfungsi sebagai alat penyebaran agama Islam, di antaranya: (a) Senjata Muballigh Islam; (b) Etos Kerja: Pekerja, Pengusaha dan Perusahaan yang Berkah; (c) Mengembangkan Wawasan Nusantara yang Islami; (d) Islam dan Keadilan Sosial; (e) Membina Moral Generasi Penerus; (f) Tajdid (Pembaruan) Dalam Islam, ${ }^{44}$ dan lain sebagainya. Buku-buku tersebut ditulis oleh para ulama dan dai Al Jam'iyatul Washliyah.

Besarnya sumbangan yang dapat diberikan melalui dakwah dengan tulisan itu, maka Al Jam'iyatul Washliyah sejak dari awal sudah aktif menyebarkan ajaran Islam dengan media tulisan, seperti menerbitkan majalah, jurnal, risalah, buku dan sebagainya. Melihat hal ini maka pengadaan terhadap taman bacaan dan perpustakaan sudah semestinya menjadi target yang harus direalisasikan oleh Al Jam'iyatul Washliyah. ${ }^{45}$ Namun kenyataan ini masih sangat mengecewakan, jika

${ }^{41}$ Al Jamijatoel Washlijah, A/ Jamijatoel Washlijah Congress ke-III Jubileum 10 Tahoen (t.t.p.: Congress Al Jamijatoel Washlijah, 1941), h. 72.

${ }^{42}$ Syamsuddin Ali Nasution, Al Jam'iyatul Washliyah dan Perannya dalam Dakwah Islamiyah di Indonesia (Disertasi: Universitas Malaya Kuala Lumpur, 2001), h. 268.

${ }^{43}$ Nukman Sulaiman, Peringatan: Al Djamijatul Washlijah 1/4 Abad (Medan: Pengurus Besar Al Djamijatul Washlijah, 1955), h. 106.

${ }^{44}$ Syamsuddin Ali Nasution, Al Jam'iyatul Washliyah dan Perannya dalam Dakwah Islamiyah di Indonesia (Disertasi: Universitas Malaya Kuala Lumpur, 2001), h. 269.

${ }^{45}$ Nukman Sulaiman, Peringatan: Al Djamijatul Washlijah 1/4 Abad (Medan: Pengurus Besar Al Djamijatul Washlijah, 1955), h. 342. 
dilihat diberbagai kantor pengurus maupun madrasah atau sekolah Al Jam'iyatul Washliyah masih jauh ketersediaan buku-buku yang diharapkan.

Ulama Al Jam'iyatul Washliyah memiliki visi yang jauh ke depan, proses pendidikan dan dakwah akan berakhir seiring dengan bertambahnya usia para guru dan ulama yang mengajarkan ilmunya, untuk itu diperlukan media yang akan digunakan untuk menyampaikan berbagai ilmu yang pernah diajarkan tersebut. Sebuah pemikiran yang dituangkan dalam karya tulisan tidak akan pernah mati selagi tulisan itu masih dibaca dan dipelihara dengan baik. Kondisi ini menjadi perhatian ulama Al Jam'iyatul Washliyah, sehingga dibentuklah berbagai media yang akan menjadi perentara antara ulama, organisasi Al Jam'iyatul Washliyah, anggota dan masyarakat luas.

\section{Aktivitas Politik}

Pada masa Jepang menduduki Indonesia, Muhammad Arsyad Thalib Lubis lebih memilih menjadi petani daripada bekerjasama dengan penjajah Jepang. Dengan keberanian luar biasa sebagai seorang pejuang 1945, beliau menulis buku yang berjudul Tuntunan Perang Sabil, buku ini ditulis dengan tujuan untuk membangkitkan semangat pemuda-pemuda Islam melawan tentara Belanda dan Jepang. "Semangat juang pantang menyerah dan tidak ada waktu kompromi terhadap penjajah, memaksa Muhammad Arsyad Thalib Lubis dimasukkan oleh Belanda ke dalam tahanan Sukamulia Medan pada tahun 1948, dan saat itu pula kedukaan yang tidak pernah terlupakan terjadi pada beliau, istri tercinta dipanggil Allah pada usia 35 tahun". ${ }^{46}$

Pasca kemerdekaan Negara Kesatuan Republik Indonesia, Muhammad Arsyad Thalib Lubis kembali berjuang bersama seluruh anggota Al Jam'iyatul Washliyah melalui Partai Masyumi. Pada tahun 1953 seluruh organisasi Islam bergabung bersama Masyumi, ${ }^{47}$ tidak terkecuali Al Jam'iyatul Washliyah. Pada akhirnya mengantarkan Muhammad Arsyad Thalib Lubis menjadi anggota Konstituante (anggota DPR) hasil pemilihan umum (Pemilu) tahun 1955. Pada pemilihan umum kali ini Masyumi masuk sebagai empat besar bersama tiga partai lainnya yaitu: Partai Nasional Indonesia (PNI), Nahdlatul Ulama (NU), dan Nahdlatul Ulama (NU). Tidak ada kontestan yang mampu memperoleh kemenangan mutlak

${ }^{46}$ Muhammad Arsyad Thalib Lubis, Debat Islam-Kristen Tentang Kitab Suci (Jakarta: Pengurus Besar Al Washliyah, 2002), h. 29-30.

${ }^{47}$ Hakimuddin Lubis, Bulan Sabit Berbintang Lima Dalam Kenangan Hidup H. Djalaluddin Lubis (Medan: t.p., 1980), h. 35. 


\section{Rozali}

atau secara mayoritas. Berikut hasil pemelihan umum tahun 1955: (1) PNI 8,4 juta suara (22,3\%); (2) Masyumi 7,9 juta suara (20,9\%); NU 6,9 juta suara (18,4\%); dan PKI 6,1 juta suara (16\%). ${ }^{48}$

Pada tahun 1955, jabatan Ketua Partai Masyumi Sumatera Utara, dijabat oleh Udin Syamsuddin yang merupakan Ketua Umum Pengurus Besar Al Jamiyatul Washliyah. Demi memenangkan Masyumi, Udin Syamsuddin dan Djalaluddin Lubis sebagai pimpinan tertinggi Al Jam'iyatul Washliyah megeluarkan khitah dan instruksi umum kepada keluarga besar Al Jam'iyatul Washliyah untuk memilih dan memenangkan Masyumi. Masyumi akhirnya mendapatkan suara yang signifikan di Tapanuli Utara, sebab non-Muslim juga memilih Masyumi. Udin Syamsuddin berhasil menjadi anggota Konstituante dari Masyumi dan yang menjadi ketua Fraksi adalah Burhanuddin Harahap, sedangkan anggota fraksi partai ini antara lain $\mathrm{M}$. Nasir (kelak menjadi Perdana Menteri). ${ }^{49}$ Dari Sumatera Utara Masyumi diwakili oleh nama-nama seperti Muhammad Arsyad Thalib Lubis, M. Hasbi Assiddiqi, Salim Fachry, St. Soripada Mulia, Adnan Lubis, Osman Raliby, M. Sabri Munir, M. Ali Hanafijah Lubis, Bahrum Djamil, Abdurrahman Abdullah, Zainal Abidin, dan T. Abdul Djalil T.M. Junus. ${ }^{50}$

Pemilu tahun 1955 tidak dilanjutkan sesuai jadwal pada lima tahun berikutnya, yaitu pada tahun 1960. Hal ini dikarenakan pada 5 Juli 1959, Soekarno mengeluarkan Dekrit Presiden yang membubarkan Konstituante dan pernyataan kembali ke Undang-Undang Dasar 1945. Kemudian pada tanggal 4 Juni 1960, Soekarno membubarkan Dewan Perwakilan Rakyat (DPR) hasil Pemilu 1955, setelah sebelumnya dewan legislatif itu menolak Rancangan Anggaran Pendapatan dan Belanja Negara (RAPBN) yang diajukan pemerintah. Presiden Soekarno secara sepihak melalui Dekret 5 Juli 1959 membentuk Dewan Perwakilan Rakyat Gotong Royong (DPR-GR) dan Majelis Perwakilan Rakyat Sementara (MPRS) yang semua anggotanya diangkat presiden. ${ }^{51}$

Muhammad Arsyad Thalib Lubis, harus mengakhiri karirnya di dunia politik seiring dengan dibubarkannya partai Masyumi oleh Presiden Soekarno pada tahun 1960. Menanggapi pembubaran partai yang mengusungnya sebagai anggota Konstuante ini. Beliau, mengatakan bahwa pembubaran Konstituante dan lahirnya

${ }^{48} \mathrm{M}$. Dzulfikriddin, Mohammad Natsir Dalam Sejarah Politik Indonesia: Peran dan Jasa Mohammad Natsir dalam Dua Orde di Indonesia (Bandung: Mizan, 2010), h. 105-106.

${ }^{49}$ Dja'far, Biografi Ketua Umum Pengurus Besar Al Jam'iyatul Washliyah 1930-2015 (Medan: Perdana Publishing, 2015), h. 74.

${ }^{50} \mathrm{https} / / /$ id.wikipedia.org, diakses pada tanggal 13 Februari 2016.

${ }^{51}$ https://id.wikipedia.org, diakses pada tanggal 13 Februari 2016. 
Dekrit tahun 1959, merupakan rekayasa Presiden Soekarno untuk tetap berkuasa. "Setelah Presiden Soekarno memaksa Masyumi bubar, Muhammad Arsyad Thalib Lubis meninggalkan gelanggang politik dan beliau berkhidmat banyak mengajar, berdakwah dan menulis. Bahkan beliau menolak ketika mendapatkan tawaran untuk menjadi pemimpin Majelis Ulama Indonesia (MUI) Sumatera Utara, dengan alasan kesehatan". ${ }^{2}$

Walaupun tidak lagi berkecimpung dalam dunia politik, sebagaimana ketika menjabat sebagai anggota konstituante, semangat juang pantang menyerah kembali diperlihatkannya pada saat meletus pemberontakan kebiadaban Komunis G 30 S PKI. "Muhammad Arsyad Thalib Lubis bersama Gading Hakim dan Usman Pelly, mendirikan Dewan Imamah di Sumatera Utara guna menghadapi bahaya laten Partai Komunis Indonesia (PKI) bersama antek-anteknya".53 Muhammad Arsyad Thalib Lubis, sadar betul terhadap kondisi negara dan umat Islam saat itu, setelah Soekarno dan Partai Komunis Indonesia (PKI) berkonspirasi untuk membubarkan Masyumi. Hal ini sebagaimana dijelaskan oleh Muhamamd Syafii Maarif, mengutip perkataan AH. Nasution (1918-2000), yang menyatakan bahwa:

Partai Komunis Indonesia (PKI) yang semakin rapat dengan Soekarno, memang telah lama bekerja keras untuk melenyapkan Masyumi, saingan sipilnya yang terkuat. Oleh sebab itu dapat dipahami, mengapa Soekarno sewaktu akan menandatangani Keputusan Presiden No. 200/1960 tentang pembubaran partaipartai, sengaja memakai ungkapan yang "sedang berontak", agar Partai Komunis Indonesia (PKI) yang pernah berontak terhindar dari keputusan tersebut. ${ }^{54}$

\footnotetext{
${ }^{52}$ Muhammad Arsyad Thalib Lubis, Debat Islam-Kristen Tentang Kitab Suci (Jakarta: Pengurus Besar Al Washliyah, 2002), h. 31.

${ }^{53}$ Muhammad Arsyad Thalib Lubis, Debat Islam-Kristen Tentang Kitab Suci (Jakarta: Pengurus Besar Al Washliyah, 2002), h. 32.

${ }^{54}$ Ahmad Syafii Maarif, Islam dan Politik: Teori Belah Bambu, Masa Demokrasi Terpimpin, 1956-1965 (Jakarta: Gema Insani Press, 1996), h. 68. Pada tanggal 13 Desember 1959, Presiden Soekarno mengeluarkan Penetapan Presiden (Penpres) No: 7/1959 yang mengatur kehidupan dan pembubaran partai. Panpres itu memberi hak kepada presiden untuk menindak partai-partai yang anggaran dasarnya bertentangan dengan dasar Negara, atau pemimpinnya terlibat pemberontakan atau menolak untuk menindak anggota-anggotanya yang terlibat dalam pemberontakan. Sesudah penpres tersebut, dikeluarkanlah Keputusan Presiden (Kepres) No: 200/1960 yang dengan resmi memerintahkan pembubaran Masyumi dan Partai Sosialis Indonesia (PSI), yang diumumkan pada tanggal 17 Agustus 1960. Pimpinan partai Masyumi menyatakan partainya bubar untuk memenuhi ketentuan-ketentuan dalam kepres itu. Selanjutnya, perpolitikan Islam -setelah Masyumi bubardiwakili sepenuhnya oleh Liga Muslim dengan NU sebagai pemain utamanya, sampai masa
} 


\section{Rozali}

Keterlibatan sebagian ulama Al Jam'iyatul Washliyah dalam politik adalah dikarenakan adanya keinginan untuk menerapkan syariat Islam di tengah-tengah tatanan masyarakat Indonesia. Hal ini juga ditegaskan oleh Saiful Akhyar Lubis, sebagai berikut:

Meskipun dalam perjalanannya para ulama ini berkiprah dalam bidang sosial dan politik, hal ini dapat dilihat dengan berkiprahnya Ismail Banda, Muhammad Arsyad Thalib Lubis dan Abdurrahman Syihab sebagai anggota parlemen mewakili partai Masyumi. Meskipun pada dasarnya mereka tidak bergerak dari ide-ide politik, namun lebih mengembangkan nilai-nilai keagamaan dan keislaman dalam dunia politik. Artinya para aktivis AI Washliyah ini lebih menonjolkan nilai-nilai Islami dalam dunia politik, walaupun tidak mendapatkan tempat di parlemen. Sehingga pada akhirnya para ulama ini harus menarik diri dari dunia perpolitikan. Meskipun pada waktu itu tidak banyak figur-figur yang menonjol dalam dunia politik seperti Muhammad Arsyad Thalib Lubis. Dilihat dari kosistensi tidak menerjunkan diri dalam dunia politik dapat diketahui bahwa ulama Al Washliyah pada masa awal keberadaannya di Sumatera Utara tetap konsisten dengan pemikiran-pemikiran dan ide-ide keulamaan. Belakangan banyaknya pelajar yang melanjutkan pendidikan ke perguruan tinggi baik di dalam maupun di luar negeri di Timur Tengah terutama Universitas al-Azhar. Setelah tahun 1970-an ke atas sebagian pelajar Al Washliyah sudah beralih ke Barat dalam mengkaji keislaman. Namun bagi pelajar yang menimbah ilmu selain di Timur Tengah agak sedikit sungkan untuk dikatakan sebagai ulama, mereka lebih suka kalau dikatakan sebagai intelektual dan ilmuan. ${ }^{55}$

Hal senada juga dijelaskan oleh Edi Zuhrawardi Pane, sebagai berikut:

Masing-masing ulama Al Jam'iyatul Washliyah memiliki pandangan yang berbeda-beda mengenai dunia politik. Ustaz Muhammad Arsyad Thalib, berdasarkan referensi yang ada memiliki pemikiran jika ingin menerapkan syariat Islam (Syariat yang mengandung politik) karena ingin membentuk suatu tatanan masyarakat sesuai dengan syariat, jadi itu hanya direalisasikan dengan kekuasaan. Maka kita butuh kekuasaan untuk menerapkan syariat tersebut, sebagaimana dicontohkan oleh Rasulullah dalam menaklukkan kota Makkah. Ketika kota Makkah

Demokrasi Terpimpin itu sendiri berantakan bersama penciptanya pada akhir tahun 1965 dengan didahului oleh peristiwa pemberontakan G.30 S/PKI yang banyak menelan korban. Lihat: Ahmad Syafii Maarif, Islam dan Politik di Indonesia Pada Masa Demokrasi Terpimpin (1959-1965) (Yogyakarta: IAIN Sunan Kalijaga Press, 1988), h. 79.

55 Saiful Akhyar Lubis, Ketua Umum Pimpinan Wilayah Al Jam'iyatul Washliyah Sumatera Utara, wawancara di Sydney tanggal 29 Oktober 2015. 
sudah ditaklukkan maka mudahlah untuk menegakkan syariat Islam itu sendiri. ${ }^{56}$

Alasan Muhammad Arsyad Thalib Lubis turut aktif dalam dunia perpolitikan adalah murni untuk menerapkan syariat Islam di tengah-tengah masyarakat yang ada baik di Indonesia maupun di Sumatera Utara. Namun politik yang dianutnya adalah berdasarkan syariat Islam yang pernah dicontohkan oleh Rasul dalam membangun negara Islam di Madinah. Rasulullah terlebih dahulu membangun kekuasaan untuk menaklukkan daerah-daerah yang selama ini dikuasai oleh orangorang kafir di Makkah.

Namun politik praktis dianggapnya kurang efektif di Indonesia, maka Muhammad Arsyad Thalib Lubis mengundurkan diri sebagai anggota Dewan Konstituante, setelah partai Masyumi dibubarkan oleh presiden Soekarno. Walau tidak lagi aktif secara langsung dalam dunia politik praktis, beliau tetap berpolitik melalui dakwah-dakwah yang disampaikan di tengah lingkungan masyarakat Sumatera Utara.

\section{Penutup}

Muhammad Arsyad Thalib Lubis, sosok ulama yang sangat dihormati dan disegani tidak hanya oleh masyarakat tanpa memandang status, aliran, agama apa saja, akan tetapi oleh pemerintah dan pemimpin-pemimpin Islam. Lebih dari itu beliau juga dikenal sebagai orang yang rendah hati, hal itu sebagaimana yang terungkap pada saat M. Natsir memberikan perhatian kegembiraan terhadap kecemerlangan Muhammad Arsyad Thalib Lubis, dengan mencantumkan gelar Professor di depan namanya saat Dewan Dakwah Islamiyah Indonesia menerbitkan buku karangan Muhammad Arsyad Thalib Lubis yang berjudul Keesaan Tuhan Menurut Ajaran Kristen dan Islam. "Secara halus beliau menolaknya, walaupun pada dasarnya semua orang memandang pantas beliau menyandang gelar ini".

Selain berdakwah ke pelosok-pelosok, maka untuk mengoptimalkan aktivitas dakwah dipandang perlu untuk menyebarkan Islam melalui media cetak atau surat kabar maupun majalah. Berdasarkan pertimbangan tersebut maka Muhammad Arsyad Thalib Lubis, ditunjuk untuk pimimpin redaksi majalah Medan Is/am, beliau memang memiliki pengetahuan yang luas tentang agama Kristen.

Dalam kegiatan dakwah beliau aktif dalam zending (muballigh) Islam Indonesia, melakukan dakwah ke kampong-kampung dengan berjalan kaki untuk menyiarkan Islam di pedalaman Tanah Karo. Perjuangan yang dilakukannya tanpa

${ }^{56}$ Edi Zuhrawardi Pane, alumni Madrasah Al Jam'iyatul Washliyah, wawancara di Medan, tanggal 29 Juni 2015. 


\section{Rozali}

henti ini menuai hasil yang memuaskan dengan masuk Islamnya puluhan ribu orang dari daerah tempatnya berdakwah. Bahkan menjelang akhir hayatnya beliau juga masih menyempatkan diri untuk pergi ke Kutalimbaru, Kabupaten Deli Serdang, untuk mengislaman sekitar dua ratus orang masyarakat di sana. Di samping berdakwah, beliau juga membagi-bagikan secara gratis buku-buku karangannya tentang shalat, iman dan ibadah dalam bahasa Karo, Nias dan Simalungun.

\section{Daftar Pustaka}

A. Djalil Muhammad dan Abdullah Syah, Sejarah Da'wah Islamiyah dan Perkembangannya di Sumatera Utara. Medan: Majelis Ulama Daerah TK. I Provinsi Sumatera Utara, t.t.

Ahmad Syafii Maarif, Islam dan Politik: Teori Belah Bambu, Masa Demokrasi Terpimpin, 1956-1965. Jakarta: Gema Insani Press, 1996.

Al Jamijatoel Washlijah, Al Jamijatoel Washlijah Congress ke-III Jubileum 10 Tahoen. t.t.p.: Congress Al Jamijatoel Washlijah, 1941.

Chalidjah Hasanuddin, Al Jam'iyatul Washliyah 1930-1942: Api Dalam Sekam di Sumatera Timur. Bandung: Pustaka, 1988.

Departemen Agama Republik Indonesia, Organisasi A/ Washliyah di Sumatera Utara. Semarang: Balai Penelitian Aliran Kerohanian/Keagamaan, 1994.

Hakimuddin Lubis, Bulan Sabit Berbintang Lima Dalam Kenangan Hidup H. Djalaluddin Lubis. Medan: t.p., 1980.

http://insistnet.com. Diakses pada tanggal 19 Februari 2015.

Ja'far, Biografi Intelektual Ulama-Ulama Al Washliyah. Medan: Centre for Al Washliyah Studies, 2012.

M. Dzulfikriddin, Mohammad Natsir Dalam Sejarah Politik Indonesia: Peran dan Jasa Mohammad Natsir dalam Dua Orde di Indonesia. Bandung: Mizan, 2010.

Martin Van Bruinessen, Kitab Kuning, Pesantren dan Tarekat. Yogyakarta: Gading Publishing, 2012.

Muhammad Arsyad Thalib Lubis, Debat Islam-Kristen Tentang Kitab Suci. Jakarta: Pengurus Besar Al Washliyah, 2002.

Nukman Sulaiman, Peringatan: A/ Djamijatul Washlijah 1/4 Abad. Medan: Pengurus Besar Al Djamijatul Washlijah, 1955.

Pengurus Besar Al Jam'iyatul Washliyah, Debat Islam dan Kristen Tentang Kitab Suci, cet. 2. Medan: Majelis Dakwah Pengurus Besar Al Jam'iyatul Washliyah, 2002. 
Syamsuddin Ali Nasution, Al Jam'iyatul Washliyah dan Perannya dalam Dakwah Islamiyah di Indonesia. Disertasi: Universitas Malaya Kuala Lumpur, 2001.

Tim Penulis Institut Agama Islam Negeri (IAIN) Syarif Hidayatullah, Ensiklopedia Islam Indonesia. Jakarta: Djambatan, 1992.

www.kabarwashliyah.com. Diakses tanggal 12 Agustus 2015. 